\title{
ADAM BODNAR CITIZENS OMBUDSMAN - AN EXAMPLE OF SUCCESSFUL ADVOCACY CAMPAIGN
}

\begin{abstract}
The Polish Senate approved the election of Dr Adam Bodnar for the position of Ombudsman on $7^{\text {th }}$ of August 2015. It happened because of the social campaign "Adam Bodnar Citizens' Ombudsman," which was held by a non-governmental organization called Citizens Network Watchdog Poland. This text is a detailed description of this campaign on the basis of data collected from qualitative research. The author has prepared a basic SWOT analysis of this case study. This article is an example of a successful advocacy campaign, which was conducted by a non-governmental organization and has led successfully to exert real influence on the decisions of politicians, who themselves decide who will be the new Ombudsman for the term 2015-2020. This article was written in cooperation with Citizens Network Watchdog Poland for the program Pracademia.
\end{abstract}

\section{Key words}

advocacy campaign, civic campaign, advocacy, ombudsman, social campaign

* Faculty of Political Sciences and International Studies, Nicolaus Copernicus University in Toruń, Poland, e-mail: ewelinawojciechowska@hotmail.com 


\section{Introductory issues}

The Polish Senate approved the election of Dr Adam Bodnar for the position of Ombudsman on $7^{\text {th }}$ of August 2015. Thus he took office on September 9 of the same year. There was a social campaign called "Adam Bodnar Citizens' Ombudsman," which was held by a non-governmental organization Citizens Network Watchdog Poland. This initiative is unusual at least for several reasons. First of all elected spokesman, Adam Bodnar he announced that he is a contender for this position. He had no political base, and only the conviction of its competence and experience. Such a situation has never occurred; moreover, the candidate came from environmental and social organizations that repeatedly criticized politicians, whose support was necessary in this case. According to the legal procedure, a group of at least 35 deputies could present a candidate for the office discussed. Were it not for the broad support of dozens of non-governmental organizations and the local media and their active efforts to propose a candidate for the widest possible political environment - in practice more than one parliamentary club, this selection by the Parliament and approval by the Senate would probably not be possible.

In the context of the topic it should be recalled that the Ombudsman is a constitutional, independent of other bodies and independent in their activity, authority of the state, who operates on the basis of art. 80 and 208-212 of the Constitution and the Act of 15 July 1987 On the Ombudsman ("Rzecznik", 2016). $\mathrm{He}$ is appointed by the Parliament with the consent of the Senate for a period of five years. Following the Law on Ombudsman (Ustawa 1987/123) he upholds the rights and freedoms of man and citizen. The Ombudsman first of all examines whether as a result of action or inaction of bodies, organizations and institutions, obliged to respect and implement these rights and freedoms, there has been a violation of law or principles of coexistence and social justice. According to the cited Act, a candidate must have Polish citizenship, vast legal knowledge, professional experience and high prestige due to requirements of displaying moral values and social sensitivity. The candidate himself repeatedly said in the media that he is a person well prepared to perform this function (Leśniewicz, 2015, Burnetko, 2015, „Adam Bodnar: System prawa”, 2015, Siedlecka, 2015) ${ }^{1}$

1 Adam Bodnar said in an interview "I worked in the Foundation for over 10 years and this was the period in which I got a lot of experience in different fields of law where 
Standard among modern countries is the existence of a number of authorities of control functions such as the institution of Ombudsman. His work in modern democracies can be broadly divided into three fields: 1 - the right to individual interventions - to solve individual cases with difficulties in their consideration of the result of error specific official; 2 - system actions - aimed at defective or not civic regulations, as well as defectiveness practice on a wider scale. The Ombudsman should indicate a need for fundamental changes in law or practice; 3 - spreading the legal culture - in the broadest sense of the word (Kowalska, 2014, p. 175). It should be remembered that the Ombudsman has no statutory authority, which would allow him to change, repeal or suspend the operation of the impugned decision, even that which violates the rights and freedoms of man and citizen. The Ombudsman may not impose that the case had been decided in a certain way by him. The substantive outcome of the case is beyond his power. (Kowalska, 2014, p. 171). Therefore, it can be said that the role of the Ombudsman is to create additional forms of protection for citizens whose rights are being violated while respecting the competence of other authorities. The Ombudsman as the office is much more accessible, it works in a less bureaucratic way and often for free. This gives a chance to use solutions less complicated for the average person than other institutions of a similar type (Banaszak, 2009, p. 65).

This text is a detailed study along with an attempt to evaluate the abovementioned campaign. It was carried out based on the analysis of existing sources, namely experts' papers, journalistic studies, candidate's website ('Strona internetowa", 2015) and a dedicated event on Facebook (“Oficjalne wydarzenie", 2015). In order to expand, however, this set of information, as well as for verification of obtained conclusions, the author led to another source being examined. They were carried out for two additional in-depth individual interviews. The talks were conducted with the main organizers of the campaign - members of the association of Citizens Network Watchdog Poland. Interviews were preceded by a detailed analysis of the content on the Internet desk research in the search for sources of information about the campaign. The study was designed to answer

various human rights are not respected and neglected. I have some serious scientific achievements in the field of human rights. It seems to me that this is a good time if I have this experience and expert knowledge, while knowing what competences the Ombudsman has, I can make really great and lasting changes in this area. I am convinced that the use of the competence of the non-governmental sector, where we operate only through such a general influence on reality, in combination with the instruments that are under the Constitution and the Act at the disposal of the Ombudsman, can give a good effect in the form of organic repair of reality in many areas. (K. Sobczak, 2015)". 
the question of how the campaign was carried out, what is behind its success and what regularities can be found that could be useful in planning such campaigns in the future also by other organizations. The collected material was allowed to describe the course of the campaign using case studies and create a SWOT analysis, which reorganized and helped put together the most important aspects of this issue. Desk research and interviews were conducted in February 2016. This is about half a year after the end of that campaign.

For a start it is worth explaining why the discussed campaign is called advocacy and what it actually means. But first it is worth knowing what are watchdog organizations. Their actions come from the idea of building a civil society and are created in order to solve social problems. Their task is to take interest in, signaling or lobbying for a change that is advantageous from the point of view of the public interest (Bartnik, 2015, p. 146, 148). To do this, they use different tools like even monitoring, lobbying and advocacy. The concept of advocacy can also be commonly understood as action in favor of a particular change. Ryszard Skrzypiec understands it as mind control measures and intervention. In his opinion, "under the terms intervention and control we understand such actions taken by social actors that are not characterized by formal links with state institutions whose goal is to explore ways of actions of government and public administration and make some adjustments to their operation (Frączak, 2009, p. 48)". An advocacy action can take the form of civil lobbying (political action), but most often organizations take social activities - including civil pressure and education - as well as legal actions. Advocacy can therefore be understood as one of the methods of watchdog activities, or not at all controls. In the publications of the NGO Citizens Network Watchdog Poland you can find the definition of the term advocacy as "working generally in favor of some changes in the attitudes of the public administration and citizens. For example, violence against women or for access to public information. Strategic advocacy in turn, is putting forward concrete proposals to change the law or influencing specific decisions of public authorities. The latter is the most popular form of advocacy occurring in the course of implementation of watchdog projects - most often they concern only a segment of a broader issue: the rights of animals not only as a whole, for example, the conditions of animals in large farms, protection of wild animals in the Podlasie region, and so on. (...) Advocacy is an action aimed at dissemination of the results of monitoring and drawing attention to common problems. Its main goal is to induce the change. (Batko-Tołuć, n. d.)”.

What is also important is the fact that advocacy activities should be guided by ethical principles. It is an activity that refers to trust (Frączak, 2008). 
Nevertheless, the concept of advocacy is not very accurately explained by practitioners and is often mistaken for lobbying. It is also considered as an alternative to other methods of carrying out watchdog activities such as monitoring.

Citizens Network Watchdog Poland is an advocacy organization, as well as a watchdog. It is a non-governmental organization that deals with civic control over the bodies of public authority on the basis of and within the law, seeking to bring about systemic changes in the functioning of state institutions (On this subject see Batko-Tołuć, Izdebski, 2012). In their view, a condition of the proper functioning of the state is public and possibly the most complete access to public information. Their task is to facilitate citizens in getting to this information and the promotion of such legal solutions that will facilitate the participation of citizens in public affairs. It can be assumed that their vision is a state in which every citizen has an impact on policy, which is run by people elected by them in the general election directly, equally and secretly. ("Co robimy?", n. d.).

\section{Analysis of the campaign and an attempt of its evaluation}

Both members of the Network when asked in interviews why they got involved in the campaign in support of Dr Adam Bodnar, replied that it was "natural" and largely resulted from their previous experience. They recognized that drew during this working, not only of the previous success, e.g. integration together both local and national advocacy organizations, as well as to rely on the recent failures. The campaign started as a result of private requests for support by Dr Adam Bodnar. This took place when he decided to run moments after the then Ombudsman Irena Lipowicz announced that she wants to be elected for a second term (Majewska, 2015). Then, as the interviewee 1 in an interview conducted "We let ourselves imagine what we and our environment could gain. We knew theoretically that such an ally [Ombudsman - ed.] was out there, but all in all we used it rarely and only in very specialized cases" (In-depth interview 1).

It follows that so far the members of the organization did not realize what a valuable ally in their work may be the Ombudsman and until now they did not treat him as an ally in their work. The interviewee stated that the decision to support that particular person is not synonymous with taking a political position, especially that Adam Bodnar was not associated with any political party. He is known for many things, which helped both the ruling parties and the opposition. Therefore, it was very easy to decide to support his candidature. 
The decision on the involvement of the Network in the campaign undoubtedly influenced the contemporary political situation. For activists noticeable was a split in the Civic Platform Party and the fact that at the beginning no politicians mentioned that subject. Only Adam Bodnar, appearing in various media, publicized the issue of the elections. He also asked chosen politicians to declare his candidacy. He could not do it alone - it had to be done by at least 35 deputies. So far it has not happened in Poland, that an organization in a bottom-up manner convinced decision-makers to propose such and no other candidates for public office in the form of a social campaign. In addition, the candidate had very little time to promote his person. Since the announcement of his decision to the date on which it was necessary to vote on his candidacy in the Parliament only about three weeks passed. For him it was also something new and unmatched in the environment from which they descended. This opinion is confirmed by the information gathered in the framework of qualitative research (In-depth interview 1).

A number of actions taken within the framework of the campaign are divided into two stages. The first is the time of the announcement of the candidacy for approval by the Parliament, and the second time the competition between the candidates for the position of the Ombudsman until the final results, or vote in the Senate. In the first stage Watchdog Poland and the candidate himself focused on publicizing this case in the media and convincing that Adam Bodnar is the best person suitable to exercise this office. For this purpose, among others, they organized a press conference in front of the Parliament of Poland, to which came also representatives of other NGOs. At the beginning it was necessary, however, to win allies and organizations that would like to recommend him. This involved, among other things sending 460 personalized letters to MPs (In-depth interview 1).

At the same time Bodnar was focused on reaching individual communities, including specific politicians, who would give him support in the Parliament. The candidate was active in the traditional media and social networks (he maintains his official profile on Facebook and Twitter) and also attended meetings, during which spoke with politicians and fellow organizations. Most of these activities he led autonomously, often in consultation with the Watchdog, and some actions could be coordinated. On the other hand, the organization served as an auxiliary, because their individual steps resulted largely from the activities of the candidate. Nevertheless, the experience of the watchdog and their relationship with Bodnar for many years, allowed to retain a high degree of freedom in the choice of techniques and methods for the promotion of his person. According to the 
first respondent's claim, none of the parties imposed their solutions on the other. What was important for him, was the clarity of objectives (In-depth interview 1).

Meetings with politicians were crucial, since on their decision depended the success or failure of the entire project. Adam Bodnar took on this task, but it should be emphasized that he never went to the meetings alone. Once it happened that at one meeting he took with him the organizer of the campaign. In her opinion, the presence of a third person was a tactical move, the aim of which was to give the impression that Bodnar has support among citizens and is not alone in his actions. The respondent agreed to such an appointment. In her opinion, lobbying is part of advocacy, and therefore in line with the objectives of the organization, which is represented. Respondent justified her approval of the fact that thanks to this she could sense views or prejudices of the caller. This allowed her to refer to them, and thus give the opportunity to convince someone to their case. This additional presence certainly lent prestige and created an impression of a professionally and thoroughly prepared strategy (In-depth interview 1).

As it turned out, meetings planned and conducted in this way actually turned out to be successful. Though it was known that sufficient support of the Platform itself is managed to obtain a vote of the Left. Eventually the candidacy of Bodnar was put forward by two clubs: PO and SLD. It was the deliberate intention of the organizers. They wanted it to resound in the media and in the halls of the Parliament that the candidate is nonpartisan. They wanted to make it one of the leading arguments in favor of the doctor.

When it comes to media coverage afforded by the non-governmental organization it was quite simple. The Watchdog Poland prepared a dedicated event on the Facebook profile, website, application for collecting signatures in support and the necessary graphic materials. Bodnar alone and independently maintained a private profile on Facebook and Twitter. During the collaboration attempts to synchronize all these activities, there was no stiff division of roles. This was not therefore a typical campaign, in which the coordinator determines and allocates tasks to individual members of the project. To a large extent campaign materials were spontaneously created - those made to the website as well as announcements and comments published on the social media (In-depth interview 2).

Promotional activities do not constitute a major problem for the organization, because in recent years they ran a lot of smaller campaigns, where they had to take care of the involvement of people in social media or in real life. In this case, the promotion was much easier because of the candidate - he was already a recognizable person and substantively prepared to take up this office. The organizers of the campaign did not lack hard data to support the contention that 
he is the best person for the position. One interviewee does not hide that "would not have been able to do a good PR without of content. Adam Bodnar was this content. We are helped to substantive work in Helsinki [provided by the Helsinki Foundation for Human Rights - ed.], which has a reputation. In reality, we would not have pieced together so many articles, with so many news, with such a positive response, if not for what Adam did in his life so far" (In-depth interview 2).

For questions about how he dealt with negative comments on Facebook, he said "For a long time there was no crisis. They appeared only at the end just before the vote in the Parliament. Then the politicians are deemed to be involved in the discussions. Previously we recorded a high support, high commitment, only positive comments. Practically we didn't block any post. (...) We tried more to create situations than respond to individual comments. We focused on this, to show him from that good, non-governmental side" (In-depth interview 2).

The most difficult issue in the campaign was collecting signatures to make them as numerous as possible - individual and from organizations. Finally the number was not impressive: 67 organizations endorsed him formally and more than 1,600 people. According to the organizers, there was too little time to collect them, the more that it required individual contacts with each organization. It cost them a lot of work and time to convince them.

It may seem that every campaign requires a lot of money. In this case it did not. This was done properly at no cost. Citizens Network Watchdog Poland had to pay only for the printing of certain materials, including 560 letters addressed to the deputies and senators. The total cost of the campaign is estimated at around PLN 600, but in one interview he makes it clear that if he were to measure the campaign, including the market price of specialized PR entities - that it would be about PLN 12 000. Doubtful remains realistic estimate of the amount and the credibility of sources, which are given in the calculation of this amount. Nevertheless, the amount of PLN 600 can bring considerations whether such a small financial expenditure testified about the belief of the organizers as to certainty of winning or perhaps a weak financial condition of the organization, which has not been able to invest more resources.

To explore this issue, the researcher asked each respondent what was the strength of their actions, what worked best, since the money was not so important for them. One said that "just did not have any complexes to do it. We showed their faces, not hiding the faith that we will succeed. Many people did not believe in our success" (In-depth interview 2). The second conversationalist stressed that "a pinch of naivety was in this, but it was very important. I do not discourage. I did not think that I was tilting at windmills, there was no guarantee 
but from the beginning I worked on something that I thought had a chance of success. (...) We had a petitionary mechanism, young boys with whom we work, and they put it in one day, because I had photos and articles to be loaded, we had a petition. We have a good person from the social media - all gathered together made an impression that we are strong (In-depth interview 1)."

Table 1. SWOT analysis of the campaign "Adam Bodnar Citizens' Ombudsman"

\begin{tabular}{|c|c|}
\hline STRENGTHS & WEAKNESSES \\
\hline $\begin{array}{l}\text { - Personality and professional competence A. B. } \\
\text { - Nonpartisan candidate } \\
\text { - An extensive network of contacts of the } \\
\text { candidate and the campaign organizers } \\
\text { - Allies - Local and national NGOs } \\
\text { from different backgrounds } \\
\text { - Unflinching belief in the success of the team } \\
\text { - Transparency goals - a clear vision } \\
\text { of W. P. and A. B. } \\
\text { - High quality of debate in the media } \\
\text { (no negative messages) } \\
\text { - The presence of opinion leaders in the media } \\
\text { - Involvement of the candidate's campaign } \\
\text { - The image of the organization W.P. } \\
\text { - Experience of organization } \\
\text { - Competence of team organization } \\
\text { - A good information flow between W.P. and A. B. } \\
\text { - Notification by two deputies clubs } \\
\text { - Live discussions and a lot of positive comments } \\
\text { and statements of support for A. B. on Facebook }\end{array}$ & $\begin{array}{l}\text { - Nonpartisan candidate } \\
\text { - No budget for the campaign } \\
\text { - Lack of time for action } \\
\text { - Conservative candidate's professional } \\
\text { environment } \\
\text { - Poor use of social networks profiles } \\
\text { other than Facebook } \\
\text { - Low intensity activities before the vote } \\
\text { in the Senate } \\
\text { - A small number of signatures under } \\
\text { the initiative of the individual } \\
\text { - W. P. as an assistant and not an organizer } \\
\text { of the campaign } \\
\text { - It's hard to evaluate which actions } \\
\text { (or organization or the candidate himself) } \\
\text { affect the course and outcome of the campaign }\end{array}$ \\
\hline OPPORTUNITIES & THREATS \\
\hline $\begin{array}{l}\text { - The political situation - a split in the PO } \\
\text { - Lack of a strong competitor } \\
\text { - Subject was not a priority for the political } \\
\text { parties } \\
\text { - Competitors did not have an active campaign }\end{array}$ & $\begin{array}{l}\text { - Treatment dismissive appeal organization } \\
\text { by politicians } \\
\text { - Voting on the current ombudsman } \\
\text { - Insufficient number of votes in favor } \\
\text { in the Senate } \\
\text { - Lack of precedent in history } \\
\text { - A small response from organizations and } \\
\text { a small number of signatures for the initiative } \\
\text { - Negative campaign environments } \\
\text { that are against, for example organizations } \\
\text { of persons with disabilities }\end{array}$ \\
\hline
\end{tabular}

Source: own. 
Interviews and analysis of press reports in the media have generated a lot of valuable information that cannot be stated here. Therefore, the researcher prepared a SWOT analysis of the campaign. This is nothing but an analytical procedure that allows to collect and organize data and clear their presentation ("Definicje", n. d.). Presented below is a basic development without analyzing the risks and opportunities or strengths and weaknesses, because that was not executed post factum. It is intended only to organize knowledge and allow for a holistic view of the campaign.

An important part of qualitative research were questions about recommendations for other advocacy organizations engaged in this type of campaign or in similar ones. One of the interviewees mentioned the foundations that are necessary in the activities of advocacy and watchdog. Certainly it is worth to prepare for the campaign in advance. Approaching the planning of the entire project should seriously reflect on its aims to clear the answer to the question: what is it for? Only then you can proceed to the objectives: even look for allies in the media, social media channels, in the local environment. You have to make contact with them to engage them to work together. It should in this case be natural and sincere to show their faces, be yourself. Here it is very important that people who are behind it are taking, have developed communication skills to a higher degree. As a result, usually longer before making the decision to organize advocacy campaigns, it has a certain base. Contacts are a valuable resource here, because no matter what would happen, it is understood that individuals and organizations can demonstrate great commitment and willingness to co-realization of these activities. These allies, who well understand the issue, are credible in the eyes of the public. They can without undue control by the organizers promote the ideas of the campaign, especially on the Internet, including the social media (In-depth interview 2).

It should be recalled that the Citizens Network Watchdog Poland is an umbrella organization whose mission is to integrate and support advocacy and watchdog organizations in Poland. Interviews revealed that communication is very important to manage this organization. In their team on a permanent basis employed is the person who deals only with the issue. Screened members of the Network recognize that other third sector organizations still have an enormous problem with this. It concerns the fact that there are no persons responsible for communication, even in the social media or persons with relevant expertise to manage such a process. In addition, the social workers do not know how these competencies are assessed in the recruitment process. Often they confuse them too, e.g. that a person employed as a fundraiser is also a person of communication. 
Callers recommend to focus on the development of the area, just to be more effective in their actions (In-depth interview 2).

Besides, the qualitative part of the study is entitled to bring another postulate. The point is that an organization must consciously build its image and this is a long-term process. This applies also to showing the effects of their actions. It would be one of the key elements of this work (In-depth interview 2).

With regard to typical activities, one of the interviewees said that in this type of business you have to use all the methods that are available, but that does not mean that you can break any rules. Each watchdog operates on the basis of and within the law. If the situation is to encourage, you can use such methods even as lobbying. As it was summarized at the end of a conversation, "you need these rules to follow, you need to document, you have to have patience, to build its position consistently deal with data subjects, probably survive any number of disasters, you should start to meet, it is important to acquire allies and thinking about who can help you and when, but you must first have something to say. As you will have no arguments that have nothing to gain" (In-depth interview 2).

\section{Summary}

This article is an example of a successful advocacy campaign, which was carried out by a non-governmental organization and led successfully to exert real influence on the decisions of politicians, who themselves decide who will be the new Ombudsman for the term 2015-2020. In support of the campaign involved were 67 organizations, right-wing and left-wing local media, and more than 1,600 individuals. There was also the official support of the scientific and legal organizations, from which the candidate originates. A unique achievement was that this NGO community, in a bottom-up led to changes in the prevailing habits - they could unite in an important case for them without incurring almost no financial resources and carry out advocacy in a very short time. Citizens Network Watchdog Poland, who coordinated and integrated organizations supporting Adam Bodnar, in the past has led other campaigns and initiatives for the implementation of good changes in the law, but rarely they reached wide media coverage.

Half a year later social workers' efforts were appreciated. In the sixth edition of the Award of Radio TOK FM as „, unique impact on reality” nominated were Adam Bodnar and Coalition of Non-Governmental Organizations. Among them were: Jerzy Owsiak, Dr Marek Bachański and Dorota Gudaniec. The nominees were chosen by the editors of Radio TOK FM among the proposals submitted by 
both listeners and visitors of this radio. Finally, the prize was awarded to Adam Bodnar. The ceremony took place on $5^{\text {th }}$ April 2016 in the Museum of the History of Polish Jews in Warsaw (Adam Bodnar i koalicja, 2016).

Because of this campaign, the organization showed how effective the impact of watchdog organizations and advocacy organizations could be and how they can influence the actions of politicians. Among the factors that determined the success of their business were mainly: unshakable belief in success, clarity of purposes, a good team of people with skills, previous experience and the name of the organization, built for more than ten years. On the other hand, the project laid bare the weaknesses of the organization Watchdog Poland, like the questionable level of professionalization of their activities or low effectiveness in raising funds, and thus weak financial condition of the organization.

There is no one recipe for a successful advocacy campaign. The description of the campaign in support of Adam Bodnar can provide an excellent lesson for the future for other advocacy organizations. Certainly it was a valuable experience for the Citizens Network Watchdog Poland. This initiative received a bigger impact on the work of policy makers and become perceived in the eyes of its stakeholders as an even more effective.

\section{REFERENCES}

Adam Bodnar i Koalicja Organizacji Pozarządowych z Nagrodą Radia TOK FM. (2016). Retrieved from www.wyborcza.pl/1,75478,19872951,adam-bodnar-i-koalicja-organizacji-pozarzadowych-z-nagroda-radia.html\#ixzz45EZOc6hQ.

Adam Bodnar: System prawa jest tworzony pod silniejszych, a nie słabszych. (2015). Retrieved from www.rdc.pl/informacje/adam-bodnar-system-prawa-jest-tworzonypod-tych-silniejszych-a-nie-slabszych-posluchaj.

Banaszak, N. (2009). Skuteczność działania Rzecznika Praw Obywatelskich - podstawowe problemy. Studia Lubuskie. Vol. V, 65.

Bartnik, A.S. (2015). Organizacje strażnicze - partnerzy czy pieniacze? Kontrola i rekomendacje jako zewnętrzny audyt ekspercko-obywatelski. In M. Piotrowska-Trybull (ed.), Społeczeństwo, gospodarka, sity zbrojne - relacje i wyzwania (pp. 146, 148). Warszawa: AON.

Batko-Tołuć, K., Bura B. Podsumowanie 2015 roku. (2016, January 7). Retrieved February 21, 2016, from http://siecobywatelska.pl/podsumowanie-2015-roku/

Batko-Tołuć, K., \& Izdebski, K. (2012). Organizacje strażnicze w Polsce. Stan obecny, wyzwania, perspektywy. Warszawa: Instytut Spraw Publicznych.

Batko-Tołuć, K. Czym jest rzecznictwo? (n. d.). Retrieved from www.archiwum.watchdogportal.pl/wwwdane/files/rzecznictwo.pdf. 
Burnetko, K. (2005). Obrońca praw człowieka nowym RPO?. Retrieved from www.polityka.pl/tygodnikpolityka/kraj/1623331,1,obronca-praw-czlowieka-nowym-rpo.read.

Co robimy? (n. d.). Retrieved from www.siecobywatelska.pl/co-robimy.

Definicje. (n. d.). Retrieved from www.analiza-swot.pl/dowiedz-sie-o-swot/definicje.

Frączak, P. (2009). Wady i zalety dobrego obyczaju kontroli społecznej. Studia i Materiały Centrum Edukacji Przyrodniczo-Leśnej, 1, 48.

Frączak, P. (2008). Rzecznictwo, czyli co? Retrieved February from www.wiadomosci. ngo.pl/wiadomosc/341085.html.

In-depth interview 1. Conducted February 5, 2016. The author's own archives.

In-depth interview 2. Conducted February 9, 2016. The author's own archives.

Kowalska, M. (2014). Instytucja Ombudsmana jako czynnik demokratyzacji systemów państwowych w krajach Europy Środkowo-Wschodniej i Południowej. Przegląd Politologiczny, 2, 171, 175. DOI: 10.14746/pp.2014.19.2.11.

Leśniewicz, K. (2015). Polska to nie tylko Warszawa i jej problemy. Retrieved from www. tygodnikprzeglad.pl/polska-to-nie-tylko-warszawa-i-jej-problemy-2

Majewska, D. (2015). Politycy, precz z łapami od Rzecznika Praw Obywatelskich! To my powinniśmy decydować, kto będzie nas reprezentowat. Retrieved from www. natemat.pl/147725,politycy-precz-z-lapami-od-rzecznika-praw-obywatelskich-tomy-powinnismy-decydowac-kto-bedzie-nas-reprezentowal.

Oficjalne wydarzenie dotyczące kampanii na portalu Facebook. (n. d.). Retrieved from www.facebook.com/events/356394714556792.

Rzecznik. (n. d.). Retrieved from www.rpo.gov.pl/pl/content/rzecznik.

Siedlecka, E. (2015). Kto na RPO? Irena Lipowicz czy Adam Bodnar? Retrieved from www.wyborcza.pl/1,75478,17976280,Kto_na_RPO__Irena_Lipowicz_czy_Adam_ Bodnar_html\#TRrelSST.

Sobczak, K. (2015). Adam Bodnar: Rzecznik powinien być bardziej aktywny. Retrieved from www.lex.pl/czytaj/-/artykul/adam-bodnar-rzecznik-powinien-byc-bardziejaktywny.

Strona internetowa kampanii. (n. d.). Retrieved from www.naszrzecznik.pl.

Ustawa (1987/123) of 15 July 1987 o Rzeczniku Praw Obywatelskich, Dz.U. 1987 nr 21 pos. 123. 